\title{
A qualitative research synthesis exploring professional touch in healthcare practice using the threshold concept framework
}

\author{
Wearn, A
}

http://hdl.handle.net/10026.1/14887

10.1007/s10459-019-09901-9

Advances in Health Sciences Education

Springer (part of Springer Nature)

All content in PEARL is protected by copyright law. Author manuscripts are made available in accordance with publisher policies. Please cite only the published version using the details provided on the item record or document. In the absence of an open licence (e.g. Creative Commons), permissions for further reuse of content should be sought from the publisher or author. 
Running title: Synthesis of professional touch explored using the threshold concept framework

\section{A qualitative research synthesis exploring professional touch in healthcare practice using the threshold concept framework}

Andy Wearn ${ }^{1}$, Lynn Clouder ${ }^{2}$, Sarah Barradell ${ }^{3,4} \&$ Hilary Neve ${ }^{5}$

1. The University of Auckland, New Zealand

2. Coventry University, UK

3. La Trobe University, Australia

4. Swinburne University of Technology, Australia

5. University of Plymouth, UK

Corresponding author

A/Prof Andy Wearn

Medical Programme Directorate

Faculty of Medical \& Health Sciences

The University of Auckland

Auckland 1142

New Zealand

E: a.wearn@auckland.ac.nz

T: +649923 8953 
Running title: Synthesis of professional touch explored using the threshold concept framework

\begin{abstract}
Touch is an integral part of human life. Consequently, touching and being touched are also fundamental to healthcare practice. Despite a significant literature on touch, it is rarely conceptualized or discussed in terms of the student journey from layperson to practitioner. We chose to explore professional touch using the Threshold Concepts Framework (TCF), which provides a theoretical model for exploring the way in which learners encounter, engage with and understand fundamental concepts in a discipline.
\end{abstract}

This qualitative research synthesis (QRS) describes the use of the TCF to identify key issues involved in developing and using professional touch. Through a cross-professional analysis and synthesis of recent international literature, we aimed to identify key characteristics of the transitional journey for professional touch. Three orders of analysis were applied, employing a methodology described by Major and Savin-Baden (2010). Following identification of threshold characteristics in the overall sample of articles, second order analysis revealed the nuances of professional touch associated with the characteristics. The final synthesis led to identification of five themes: touch as dialogue; being changed by touch; multiple boundaries of touch; multiple meanings of touch and influences on touch.

Whilst providing support for some assertions within the literature, this QRS also offers new insights into the complexity of professional touch. Given the paucity of explicit learning and reflection around professional touch in training programmes of health professionals, the TCF reveals ways in which professional preparation might be improved to promote understanding of the role and impact of touch in practice.

\title{
Keywords
}

Health professions; professional touch; qualitative research synthesis; threshold concepts 
Running title: Synthesis of professional touch explored using the threshold concept framework

\section{Introduction}

Touch is part of human interaction; it is manifest socially, relationally, culturally and professionally. Touching, and simultaneously being touched by another person, is an integral aspect of being human (Chang, 2001). Touch is the initial sense to develop in humans, but is often overlooked in terms of its complexity both as a sense and in human interaction (Moffat and Kerry, 2018). Physical contact with others is a language in itself, modifying behaviour and affecting emotions (Gallace and Spence, 2010). Context and culture also influence the experience of interpersonal touch (Gallace and Spence, 2010) which is important when considering healthcare. Consequently, there are marked differences in the 'rules' that apply to touch in everyday and professional contexts. Healthcare makes considerable use of touch, and for most health professionals it is essential to their practice. Students and novice health practitioners need to navigate many transitions, one of these being the development of a professional approach to touch. They need to repurpose social touch, negotiate sensitive touch, and develop skills in touching for assessment and treatment. The suggestion that "touch is so much more than touch" (Verghese, 2009, p. 1178) hints at the complexity of developing professional touch when moving from lay to professional understandings and capabilities. These challenges underpin our rationale for this focused study of the issues surrounding professional touch, in an attempt to understand and improve support for health professional students in acquiring and using tactile capabilities. A further motivation in foregrounding professional touch as a complex concept is that touch seems to feature less prominently in modern healthcare practice (Kelly et al., 2015). The drive to increase productivity and a reliance on technology is changing the role of touch in practice. In therapy services, no-touch techniques are being enforced, whilst more broadly the emphasis on imaging and lab results, risk touch becoming obsolete (Gadow, 1984). Concerns related to defensive practice may also have contributed to a withdrawal from touch in some aspects of 
Running title: Synthesis of professional touch explored using the threshold concept framework

care (Singh and Leder, 2012). Yet a simultaneous recognition of the need for holistic care and usefulness of high-touch strategies, for example in dementia and cancer care (Nicholls et al., 2013; Tabatabaee et al., 2016), support touch as an essential capability for health professionals.

Touch has been described as a 'silent language' and a significant component of non-verbal communication (Peloquin, 1989). For the health professional, touch is diagnostic (e.g. taking a peripheral pulse, examining the abdomen), therapeutic (e.g. applying a dressing, mobilising a joint) and expressive (e.g. a demonstration of empathy, a signal of partnership). Touch has physical, emotional, social, cultural and spiritual significance (Chang, 2001). Merleau-Ponty (1962) refers to "knowledge in the hands" (p.144) to convey the idea that the sensory input from touch provides an additional source of information on which the healthcare practitioner can base assessment or treatment decisions, or simply convey their empathy.

The literature on professional touch is diverse, discursive and extensive, yet understandings are relatively superficial and largely descriptive. There have been only limited attempts to consider the process and impact of developing professional touch capabilities on novice professionals, and no attempts, to our knowledge, to conceptualise or build theory around this transition.

\section{The Threshold Concepts Framework (TCF) and the threshold nature of professional touch}

Threshold concepts are held to be central to the mastery of a subject or discipline. Concepts can be described as 'threshold' when they exhibit certain characteristics which constitute the TCF (Meyer and Land, 2003, 2005). The characteristics of a threshold concept are given in

Table 1. These characteristics have been identified across many disciplines and contexts.

Every characteristic may not feature in any particular threshold concept, although Land et al. 
Running title: Synthesis of professional touch explored using the threshold concept framework

(2016) suggest that the transformative and integrative features are definitive markers of status as a threshold concept, and troublesomeness and irreversibility are frequent and likely. More pointedly, transformation is said to be a non-negotiable threshold characteristic (Timmermans and Meyer, 2017), and it has been suggested that troublesomeness is of particular importance in health professional contexts (Neve et al., 2016).

\section{INSERT TABLE 1 ABOUT HERE}

An underlying idea of threshold concepts, embedded in the metaphor of a physical threshold or doorway, is of liminality - being in a threshold space, between one thing and another. Being in the liminal space causes a learner to stop; for example, because learning is troublesome, requires integration or a change in self. In liminality, learners encounter, engage, and hopefully cross over and move on once a threshold concept is grasped. Crossing the liminal space towards new understandings is revelatory, yet by no means, unproblematic, as other threshold concepts characteristics indicate. Coming to understand a threshold concept is described as "akin to a portal, opening up a new and previously inaccessible way of thinking about something" (Meyer and Land, 2003, p. 412). The TCF is widely used in educational research and practice across a wide range of disciplines (Flanagan, 2018) including in health professional practice in which there is a growing literature (Neve et al., 2016; Barradell and Peseta, 2017).

The TCF stood out to us as a useful theoretical basis for exploring, understanding and synthesising the issues involved in the development of competence in professional touch. Its characteristics seemed to resonate with the ways in which we have observed learners encountering, engaging with and understanding professional touch. Drawing on and integrating knowledge, skills and professional behaviours is part of a transformational journey - from not grasping its significance, to enacting it - whilst acknowledging and 
Running title: Synthesis of professional touch explored using the threshold concept framework

working with troublesomeness and recognising that this aspect of becoming professional is probably irreversible.

This paper describes a qualitative research synthesis $(\mathrm{QRS})$ of recent international literature across the health professions employing the TCF (Meyer and Land, 2003, 2005). We began with the aim of identifying whether professional touch was a threshold concept and, if so, what issues might be involved in developing professional touch. Specifically our research objectives were to:

- Explore the ways that professional touch is understood by health professionals in recent literature

- Identify which TCF characteristics apply to professional touch

- Highlight the potential complexities associated with professional touch, including the factors that may promote or interfere with its development

In addition the authors hoped that the research findings might be useful for health professional educators in informing curriculum development around professional touch.

\section{Methods}

Following consideration of a number of approaches to systematically reviewing the literature, we chose to focus on exploration and interpretation of qualitative work. A realist synthesis was considered, but a QRS approach felt better suited to our aims. We anticipated the need to be selective, whilst allowing sufficient breadth and inclusivity, and to have a clear audit trail of examples of characteristics and subsequent themes. Our method was informed by Major and Savin Baden's work (2010) that advocates QRS for interpretatively analysing and synthesising existing qualitative literature to form new knowledge and understanding. The method involves a series of iterative processes: framing the research question, designing and 
Running title: Synthesis of professional touch explored using the threshold concept framework

conducting a search strategy, selecting and gathering the literature sample, analysis, synthesis and interpretation. While there are no predefined rules regarding sample size for a QRS, and faced with a potentially large volume of data, the logic of data sufficiency is guided by perceptions of what constitutes sufficient evidence for achieving the synthesis purpose (Paterson et al., 2001). Typical advice is to aim for a small number of studies, ideally 6 to 10 , although up to 20 is acceptable (Major \& Savin-Baden, 2010).

\section{Search strategy}

Early in our discussions, four pieces of literature were formative in planning the study (Edwards, 1998; Gleeson and Timmins, 2004; Verghese, 2009; Bjorbaekmo and Mengshoel, 2016). These were used as sentinel articles in our search strategy; that is the searches needed to find these articles.

Four databases were chosen for conducting our search: Medline, EMBASE, PsycINFO and Cinahl+. These were chosen based on their coverage and well-embedded search structures. Our search strategy was designed so as not to overlook data that might reveal important insights about the research question. For example, both empirical and conceptual ('think' or opinion) articles were considered as valid qualitative literature. We used a mixture of MeSH and keyword terms covering touch, the disciplines, and aspects of practice (See Table 2). Boolean operators were used to search with multiple terms. Search limits were set to English language and publication date from 1990-2016. A summary of the inclusion and exclusion criteria used to refine the search results is provided in Table 2. We chose to exclude the patient view from our synthesis as we felt that it may have different nuances and deserved a separate analysis; our primary aim being to consider the literature focused on health professionals. 
Running title: Synthesis of professional touch explored using the threshold concept framework

INSERT TABLE 2 ABOUT HERE

This initial search, yielding 2,086 articles, was conducted by a research assistant, overseen by one of the authors (AW). After screening of abstracts by the research assistant, 879 papers appeared to meet our search criteria. These were imported into an Endnote (vX7.5, Thompson Reuters 2016) library. At this point, given the large sample, we decided to limit the search to the current decade $(2010$ - 2016), removing two decades of papers. We refined the inclusion criteria (Table 2) to reflect this change. This process left us with 228 papers. The abstracts were read by one of the authors (AW) and in some cases the full paper assessed. This led to a further cull down to 38 papers, where the aims of the synthesis appeared to be the main focus. An additional Google Scholar search for these dates and a hand search of reference lists of each paper were used to check for overlooked articles. Two of the authors (LC and AW) screened the 38 full papers for final inclusion. Any discrepancy of opinion was arbitrated by one of the other authors (SB and HN). At this stage papers were excluded for the following reasons; quantitative method (4), patient focused (7), insufficiently focused on the aims (6), thesis (1). This eventually resulted in a total of 20 papers (listed in Table 3) for the synthesis.

\section{Analysis}

The analysis included three main stages:

First Order - Each paper was read to gain a sense of its aims and purpose and to extract summary information. Each paper was then analysed using the TCF as a lens, exploring which, if any, of the eight characteristics were present in the account of professional touch. One of the authors (LC) read and analysed all 20 papers. The other 3 authors (SB, HN, AW) 
Running title: Synthesis of professional touch explored using the threshold concept framework

each read and independently analysed a proportion of all of the included papers and crossreferenced their findings (with LC) to form an agreed collective analysis.

Second Order - All articles exhibiting each of the eight TC characteristics were read as a corpus to gain an overview of each discrete characteristic. For example, professional touch was identified as troublesome in 16 of the 20 included papers - analysis of these 16 papers was conducted to explore the ways in which professional touch was described as troublesome, using the description of troublesomeness from the threshold concepts literature. These findings were summarised and emerging themes highlighted. Each author was allocated at least two characteristics to analyse and findings were shared and discussed.

Third Order - To finalize the synthesis, one author (AW) initially read all of the second order summaries in order to establish through-line interpretations - what could be said about the complexity of professional touch from a condensing of the entire body of included literature. These were shared and refined by all authors in relation to second and first order findings. The final synthesis was framed against the characteristics of the TCF.

\section{Results}

Twenty papers were included in the final synthesis (Table 3). The study details and settings represent a diverse context across which the synthesis was carried out.

INSERT TABLE 3 ABOUT HERE

\section{First Order findings}


Running title: Synthesis of professional touch explored using the threshold concept framework

Table 4 presents a summary of the first order analysis and the inherent threshold characteristics that were identified across the sample. All eight characteristics were present across the included literature, with three papers exhibiting all eight characteristics.

\section{INSERT TABLE 4 ABOUT HERE}

\section{Second Order findings}

In this section we outline the sub-themes that emerged when the literature was interrogated against each specific threshold characteristic.

\section{$\underline{\text { Transformative }}$}

Transformation was described in terms of how the act of touching changes people's insights, wellbeing and relationships. Transformation was represented in four main ways: (i) learning the many facets of touch, (ii) challenging self, (iii) improved awareness, and (iv) relationship building.

The act of touching serves many different purposes (Haslam, 2012; Green, 2013).

Procedural and expressive forms of touch are two such examples (Airosa et al., 2016) - touch serves a diagnostic or therapeutic intention but other forms of touch convey emotion or connectedness. Practitioners demonstrate transformation through a sophisticated understanding of these different intentions and their appropriate use in practice (Haslam, 2012; Cocksedge et al., 2013).

(ii) Experiences of professional touch can transform individuals' awareness and views of touch. For example, Bjorbækmo and Mengshoel (2016, p.14) described physiotherapists "being woken up, beginning to wonder," while mental health teams' conversations about touch have influenced and changed their philosophy of care (Burns, 2015). Trainees in the 
Running title: Synthesis of professional touch explored using the threshold concept framework

Alexander Technique found being touched and touching led to a personal shift, resulting in feeling more comfortable about their own bodies (Jones and Glover, 2014). In contrast, Nicholls \& Holmes' (2012) work raises the transgressionary nature of professional touch; negotiating the challenging area of intimate or taboo touch was seen as transformative for individuals in that it required attention and discipline.

(iii) Touch enables practitioners to understand their patients in unique ways as they train the hand to become the instrument on which "sensory awareness is focussed" (Carel and Macnaughton, 2012, p.1). Transformation occurs through reading and knowing the body and how the body "may be handled, transformed and understood" (Twigg et al., 2011, p.173). (iv) Many of the papers commented on the relationship building benefits of touch, with transformation based on mutuality which served to facilitate the delivery of care (Ranheim et al., 2010; Carel and Macnaughton, 2012; Haslam, 2012; Nicholls and Holmes, 2012; Nicholls et al., 2013; Cocksedge et al., 2013; Jones and Glover, 2014; Polizzi, 2015; Airosa et al., 2016).

\section{$\underline{\text { Troublesome }}$}

Whilst there are a number of forms of troublesome knowledge, two featured most commonly here: tacit knowledge (Perkins, 2006), which is often implicit, and nettlesome knowledge (Sibbett and Thompson, 2008) which is taboo or culturally/emotionally challenging. Alien knowledge (knowledge which does not fit with an individual's current understanding, views or beliefs) and inert knowledge (lacking connection to the learner's existing knowledge and experience so that the learner struggles to apply it in practice) (Perkins, 2006) were less commonly found here. Within the sample literature, troublesomeness related to: (i) culture, 
Running title: Synthesis of professional touch explored using the threshold concept framework

(ii) risk, (iii) ethico-legal-moral issues, (iv) the practice model shaping or informing the intention of touch, and (v) systems-based issues.

(i) The beliefs and attitudes of patients and/or practitioner, and the broader sociocultural contexts surrounding touch, may influence how touch is interpreted and accepted (Jones and Glover, 2014; Burns, 2015; Kosak, 2016). The intent of touch may therefore be misunderstood by patients as threatening, condescending or intimate (Burns, 2015; Whiteside and Butcher, 2015) and in certain situations touch may be considered inappropriate (Haslam, 2012). Thoughts around, and responses to touch can be influenced by gender, age, status and race (Nicholls and Holmes, 2012; Jones and Glover, 2014). There can be particular challenges for male health professionals who may stereotypically not be deemed appropriate for, or capable of, providing professional touch. Whiteside and Butcher (2015) cite examples of male nurses fearful of the contact they provided in their daily work being misinterpreted and feeling ill prepared to deal with this.

(ii) Professional touch carries with it potential risks, with risk different for patient or practitioner. Power differentials between patient and practitioner, such as age, status, health, strength and gender, often advantage the practitioner (Jones and Glover, 2014). Additionally, patients may be sedated, partially clothed, naked or lying down, while the practitioner is standing, and attempts to empower patients can be difficult (Twigg et al., 2011). For patients, risk can be associated with touch that is unwanted (Jones and Glover, 2014), causes pain or discomfort (Carel and Macnaughton, 2012; Jones and Glover, 2014; Kosak, 2016), triggers past trauma and causes psychological harm (Nicholls and Holmes, 2012; Burns, 2015) or requires exposure of body parts (Jones and Glover, 2014). Patients may feel judged on their appearance or cleanliness (Carel and Macnaughton, 2012). A particular difficulty is around acknowledging and managing the innate sensuality of touch (Twigg et al., 2011; Nicholls and Holmes, 2012). Touch may be misunderstood as sexual (Jones and Glover, 2014) and also 
Running title: Synthesis of professional touch explored using the threshold concept framework

lead patients to become sexually aroused (Nicholls and Holmes, 2012). This can be unexpected and embarrassing. For practitioners, touch can be emotionally draining, laborious and demanding and may involve the suppression, rather than expression, of emotion (Nicholls and Holmes, 2012). Without the necessary resources, energy, support and ability to cope with the target's suffering (Goetz, 2010; Green, 2013) the caregiver may themselves feel distressed, sad, powerless or unable to cope. Practitioners may experience sexism, racism, and other forms of abuse as a result of the touch they provide to others (Twigg et al., 2011). Patients might respond physically (e.g. hitting out) or verbally (e.g. complaining) (Cohen, 2011). Practitioners may feel emotional or physical unease when faced with unpleasant touching tasks, smells and bodily changes (Picco et al., 2010; Kosak, 2016) yet still feel obliged to touch (Burns, 2015). There is also stigma attached to the 'dirty work' of caregiving (Twigg et al., 2011) and power differentials, with health profession status increasing with "distance from the body" (Twigg et al, 2011, p.175)

(iii) The papers raised moral, legal and ethical issues surrounding professional touch. Effective communication is required to understand patients' wishes and, sensitively act in line with these and ensure autonomy (Burns, 2015). It might be a challenge for practitioners to address requests from patients which may conflict with their own personal values and beliefs (Burns, 2015). Instinctive responses (e.g. touch to reassure) may be guided by beneficence but may be harmful, for example, causing unintended pain (Kosak, 2016) or distress to a patient who has experienced sexual or physical abuse (Burns, 2015).

Practitioners could feel vulnerable especially if working alone, and concerns about the potential for litigation may prevent staff using touch (Cocksedge et al., 2013; Jones and Glover, 2014).

(iv) Professionals and professional bodies have different models of practice and views on touch. This can cause imbalance or divisions within a team (Burns, 2015). Reconciling 
Running title: Synthesis of professional touch explored using the threshold concept framework

biomedical practice orientations with more person-centred humanistic approaches can be troubling, difficult to integrate in practice and may even result in marginalised practices; for example, in obstetrics, some disciplines may focus on the objective and technical, displacing the subjective embodied view of other disciplines (Draper, 2014). Yet the needs and expectations of patients are changing (e.g. ageing population, rising chronic health issues) and more holistic perspectives of touch are often warranted (Nicholls and Holmes, 2012). Balancing healthcare's technological enthusiasm with soothing touch can be difficult (Haslam, 2012).

(v) Changes in health and social care systems and resourcing, for example 'care as a commodity', can make it hard to treat patients holistically (Cohen, 2011). Having to conform to strict budgets and standards can make it hard to take clients' diverse needs and circumstances into account (Cohen, 2011). Time pressed workers may also have less freedom to provide the care and touch that patient's wish and need (Twigg et al., 2011).

\section{Irreversible}

Irreversibility was the characteristic least evident in our sample of the professional touch literature. When a threshold concept is understood and mastered, it is suggested that it becomes difficult to remember what it was like to encounter and wrestle with the concept for the very first time (Cousin, 2006). Thus professional touch might be considered implicit and there is evidence in our analysis of the challenges associated with being hard to 'unknow' this capability in: (i) the novice to expert journey, (ii) the need for self-care, and (iii) ongoing development of self.

(i) Jones and Glover (2014) explored clinical psychologists' use of the Alexander technique and seemed to infer irreversibility when suggesting a relationship between the level 
Running title: Synthesis of professional touch explored using the threshold concept framework

of experience in touch, and feeling progressively more comfortable touching patients.

Similarly, Cocksedge et al. (2013) explored doctors' experience of touch, arguing that touch becomes instinctive, again presumably, with experience. Twigg et al. (2011) discussed the tensions of sexuality and touch, describing how the professional develops a less affective and gendered view with experience which resonates with the idea of irreversibility and expertise development.

(ii) In burnout, practitioners may develop self-protection strategies and detachment, including withdrawal from touch. Airosa suggests that the use of professional touch has implications for maintaining presence and connection (Airosa et al., 2016).

(iii) Touch is "fundamental for the ongoing constitution of self as a person and for the development and exercise of human intersubjectivity" (Green, 2013, p. 242) and therefore may suggest irreversibility. In neuropsychology, it has been shown that to touch is also to feel touched; there is a mirroring of neural pathway activation. This intersubjectivity develops with experience and therefore touch and its effect on us becomes part of us (Green, 2013).

\section{Integrative}

Integration was reflected in three main ways: (i) issues related to the reciprocity of touch/being touched, (ii) touch as part of being human through connections of body, mind and emotion, and (iii) touch as a form of communication central to being a health professional.

(i) The reciprocity of touch/being touched is integrative in that it frames more complex relationships between health professional and patient. Elkiss and Jerome (2012) describe the moment of contact as "an interaction of dynamic, complex systems that creates a greater system still - the patient-physician dyad - with emergent thoughts, feelings, and dialogue that are greater than the sum of the individual parts" (p.515). Being touched is not a passive act, 
Running title: Synthesis of professional touch explored using the threshold concept framework

but requires the recipient to be involved, at least in terms of active awareness (Bjorbækmo and Mengshoel, 2016). The experience of being touched by a health professional will not necessarily be experienced or made sense of in the same way by the individual who is touching (Twigg et al., 2011) - both conceptions are however important and differences here may be a source of troublesomeness (e.g. power and gender). Touch - or more broadly bodywork as it is described by Twigg et al. (2011) - involves a range of inter-subjectivities; the emotional impact of touch (and by extension, caring) on health professionals should not be overlooked. Understanding professional touch in integrative ways demands that practitioners are as much aware of themselves and their own responses, as they are of the effect on the people they are treating. This raises further issues about professional boundaries; being able to appropriately separate one's own needs from those they care for and the ability of caregivers to consequently look after their own health and wellbeing.

(ii) Appropriate and effective professional touch is a synthesis of 'head, hand and heart'. At a biological level, touch is part of a connected systems network involving the musculoskeletal, immune and endocrine systems (Elkiss and Jerome, 2012), and involving an interplay of senses (e.g. pressure, temperature, pain etc), perception and emotion (Ranheim et al., 2010; Elkiss and Jerome, 2012). The act of touching and being touched cannot be separated from being human (Nicholls et al., 2014; Airosa et al., 2016).

(iii) Touch can make certain healthcare tasks, and the overall healthcare experience, easier and more satisfying by addressing people's holistic needs (Cocksedge et al., 2013; Nicholls et al., 2014; Burns, 2015). Touch does this by being a form of conversation (Jones and Glover, 2014; Bjorbækmo and Mengshoel, 2016) involving mutual listening, feeling, responding and expression. Professional touch requires physical and emotional presence (Ranheim et al., 2010, Airosa et al. 2016; Bjorbækmo and Mengshoel, 2016). The embodiment of touch changes the way that caring and compassion are experienced and 
Running title: Synthesis of professional touch explored using the threshold concept framework

understood (Goetz et al., 2010) - shifting from a perspective that touch is merely a tool/technique (procedural touch) towards touch as integral to being a health professional and connecting with others (and also involving expressive touch) (Haslam, 2012; Jones and Glover, 2014). Understanding touch as a form of connection deepens (therapeutic) relationships - the interaction becomes one that is shared by people (rather than done to bodies). This humanistic perspective of touch is as important to contemporary health professions as biomedical or biomechanical ones have been (Nicholls and Holmes, 2012).

\section{Bounded}

Boundedness featured in several ways: (i) touch defining the boundaries between self and other, (ii) individual boundaries to touch, and (iii) touch as bounded by discipline. Many of the papers acknowledged the fluidity of these boundaries.

(i) Green (2013) suggests an important rule of touch is to identify boundaries between oneself and others. Clarifying these boundaries, and how they are established and breached, defines the concept of touch according to Twigg et al. (2011). Touch transiently breaches boundaries as patient and physician interact (Elkiss and Jerome, 2012). While touch "locates us in the world, and mark the boundaries and extension of our body" (Green, 2013, p. 251), bodies are inherently unbounded in that they leak and breakdown; nurses often purposefully breach boundaries (for example, to insert a nasogastric tube or enema) in attempting to restore more acceptable boundaries (Draper, 2014). Emotional elements of touch can also "transcend and permeate boundaries" (Twigg et al., 2011 p. 175) between work/home life of practitioners. Emotional elements of touch appear themselves to be bounded. Goetz (2010) describes, for example, how compassion is a distinct emotion, different from sadness, distress or love and involves an awareness of one's separateness from the patient. 
Running title: Synthesis of professional touch explored using the threshold concept framework

(ii) Boundaries of touch vary between individuals, might change over time and differ across cultures (Kosak, 2016). The boundary between professional touch and sexuality can be ambiguous (Twigg et al., 2011). Past experience of touch (Jones and Glover, 2014) and the age and gender of the caregiver influence patients' boundaries of acceptable touch (Cocksedge et al., 2013; Kosak, 2016). Individual professionals perceive the boundaries of touch differently and this may be influenced by personality (Cocksedge et al., 2013), gender or by the patient. Male nurses may feel a need to set tighter boundaries to minimise risks (Whiteside and Butcher, 2015) while doctors reported being more willing to touch bereaved or terminally ill patients (Cocksedge et al., 2013). While some parts of the body are considered 'safe' areas to touch, even this can vary, for example, depending on gender (Whiteside and Butcher, 2015).

(iii) Touch is also bounded by discipline and disciplinary culture (Kosak, 2016). The use and boundaries of touch varies between health professions, and may define the health discipline yet might also be contested. For example, physiotherapy's biomechanical use of touch is strongly influenced by the dominant biomedical model. This provides a legitimacy and distinctness to physiotherapy (as opposed to, perhaps, massage) but can also be seen as a constraint. Physiotherapists who breach these boundaries and offer a more holistic, expressive form of touch may be seen as transgressors, even though they are often responding to changing needs and the different ways people experience illness. (Nicholls and Holmes, 2012).

\section{Discursive}

The discursive features of touch appeared in the following ways: (i) as an alternative or transcendent language, (ii) serving different purposes and intentions, and (iii) of a reciprocal nature. Although each is discussed below in turn, the bi-directionality of touch means these features are more entangled than separate. 
Running title: Synthesis of professional touch explored using the threshold concept framework

(i) Health professionals need to convey tactile information in verbal and written format to colleagues. Palpation as part of the language of examination (Elkiss and Jerome, 2012), and therapeutic interventions in various forms, such as massage, assisted movement, mobilization and manipulation (Nicholls and Holmes, 2012), have their own system descriptors. They are all variations of what Bjorbækmo and Mengshoel (2016) refer to as 'task-orientated touch'. Notwithstanding descriptive words, Jones and Glover (2014) emphasise that "touch lacks verbal discourse in our society" (p. 140). In fact, they identify an incompatibility between touch and the spoken word, highlighting how pupils learning the Alexander technique found touch far more effective for conveying their messages than words. Professional touch seems to constitute a language of its own that transcends words. Twigg et al. (2011) referred to "listening to body-talk and body stories" (p.183), Jones and Glover (2014) to the "language of touch" (p.149) and Cocksedge et al. (2013) to "touch as a silent language" (p. e283). Cocksedge et al. (2013) also argued that touch as a communication tool is under-utilised. However our sample seems to suggest that, rather than being under-utilised, it may be an unacknowledged taken-for-granted aspect of professional practice.

(ii) Touch is ultimately part of being human and can serve different purposes (e.g. contact, intimacy or therapy) (Haslam, 2012). Burns (2015) referred to the difference between expressive and instrumental touch, which convey different meanings to the person being touched. This suggests that touch is not merely a sensation but a perception (Green, 2013) which is also linked to feelings (Elkiss and Jerome, 2012). Speaking from a nursing perspective, Airosa et al. (2016, p.17) noted that touch has the ability to convey meaning, such as "showing compassion without any other tools than the hands". Similarly, Goetz (2010) saw touch as a purposeful display of compassion intended to reduce suffering of a vulnerable other. These authors suggest that touch is symbolic and representative of underlying feelings or recognition of the needs of others. Cocksedge et al. (2013) noted the 
Running title: Synthesis of professional touch explored using the threshold concept framework

seamless use of both expressive and procedural touch, highlighting the multifunctional nature of professional touch which presumably enhances its integrative potential, allowing a more complete assessment of the biopsychosocial presentation of each patient (Elkiss and Jerome, 2012) .

(iii) Just as spoken or written language is encoded (e.g. adapted to convey a message) and decoded (e.g. interpreted by the receiver), so too is professional touch. For each individual there is oscillation between subjective and objective experience (Carel and Macnaughton, 2012). Touch is also reciprocal or bidirectional; "to touch another is to be touched back" (Elkiss and Jerome, 2012, p.517). As such, professional touch is part of a process that involves varying degrees of acceptance and relationship building. Kosak (2016) noted that gaining access to a body involves an invitation. Avoiding misinterpretation with respect to gender and cultural differences creates an additional layer of complexity (Jones and Glover, 2014; Burns, 2015; Whiteside and Butcher, 2015). Physical touch gives and receives meanings (Green 2013) which can be challenging for health professionals faced with having to touch patients whom they would rather not touch. As such, touch is "an intimate, tactile, verbal and nonverbal dialogue" (Elkiss and Jerome, 2012, p.515). Bjorbækmo and Mengshoel (2016) developed this idea further in describing touch as "a silent, touching, moving dance" (p.16) with the patient as an active participant. However, Nicholls and Holmes (2012) highlighted the ease with which boundaries may be crossed in a dialogue, thus emphasising the importance of professional regulation.

\section{$\underline{\text { Reconstitutive }}$}

Grasping a threshold concept may involve "a repositioning of the self in relation to the subject" (Meyer and Land, 2005, p.374). Green (2013, p.242) suggests that as touch is crucial to human development, “nurses' very selves as persons are being challenged by these 
Running title: Synthesis of professional touch explored using the threshold concept framework

interactions." Examples of reconstitution have been discussed earlier within the related transformative, discursive and troublesome characteristics. Additional aspects include (i) a shift in the emotional state, self esteem and wellbeing of practitioners (ii) a heightened awareness about self, how to use touch change in awareness and subsequent use of touch and (iii) a letting go of disciplinary constraints enabling practitioners to offer a more holistic approach to touch.

(i) Airosa et al. (2016) describe nurses being changed emotionally by using touch, developing a sense of satisfaction and humility. Touch requires the carer to give "a part of herself" (Jones and Glover, 2014, p.145) and while, as described earlier, this is at times emotionally stressful for carers, observing the positive impact of touch on a patient can result in health professionals finding their work more meaningful and rewarding (Twigg et al., 2011). Practitioners describe how touch leaves them feeling calmer or more relaxed with an improved sense of well-being (Green, 2013, Airosa et al., 2016). Using touch to compassionately connect with a patient can increase a nurse's self-esteem, confidence and sense of pride and value (Airosa et al., 2016; Nicholls et al., 2013).

(ii) While touching, health professionals may become more self-aware and mindful (Airosa et al., 2016) of: their own vulnerability (Carel and Macnaughton, 2012), their mortality (Green, 2013), of the emotions involved in touch as well as a deeper understanding of how to touch and be truly present with the patient (Airosa et al., 2016). An awareness and acceptance of the innate sensual and pleasant elements of touch can free practitioners from restrictive bio-medical models so that they use touch in more diverse ways (Nicholls and Holmes, 2012). Coming to appreciate the oscillation between subjective and objective elements of touch may help doctors bridge the gap between seeing the person as well as the illness (Carel and Macnaughton, 2012) 
Running title: Synthesis of professional touch explored using the threshold concept framework

\section{$\underline{\text { Liminality }}$}

Liminality is concerned with the learning journey and the identity shift associated with crossing a threshold; the change that happens both cognitively and affectively with engaged, meaningful learning that demands wrestling with uncertainty and discomfort. In this synthesis individuals became stuck or took time to change in relation to: (i) exploring their own understandings of touch, caring and intimacy, (ii) recognising different lens' through which touch could be viewed, (iii) practicalities, pitfalls and risks of touch, and (iv) the potential conflict between the system view and a personal view of touch.

(i) Becoming a health professional requires that individuals explore their own understandings of touch, caring and intimacy. It is also important to do this within workplace settings with colleagues and in reference to professional standards and codes of conduct. Individuals are frequently required to negotiate or renegotiate issues related to touch within their practice contexts (Whiteside and Butcher, 2015; Airosa et al., 2016), potentially becoming stuck in or rebounding into a liminal space.

(ii) Practitioners commonly experience a fluid boundary between the personification and objectification of the body in relation to touch (Nicholls and Holmes, 2012). This has also been seen historically and culturally in the way that professional practice has evolved. A simple shift in the position of the patient, supine to prone, can influence the view of the patient as person or object.

(iii) Power, gender, culture, role boundaries and appropriateness are all tied up in professional touch (Twigg et al., 2011; Cocksedge et al., 2013; Green, 2013). In certain situations these issues may be more troublesome for some than others; for example, male nurses employed in a female dominated workforce (Whiteside and Butcher, 2015). Some practitioners talked about their comfort with some patients and discomfort with others, where they became consciously aware of their competence and boundaries, e.g. gender or age 
Running title: Synthesis of professional touch explored using the threshold concept framework

difference. This can lead to uneasy constant vigilance (Twigg et al., 2011). A preoccupation with ethical and moral considerations is another potential consequence of liminality (Green, 2013; Jones and Glover, 2014).

(iv) Increasing regulation, dwindling resources, a growing emphasis on objective measurement and/or the emergence of new technologies have changed the use of some aspects of professional touch, most notably expressive forms, in order to minimise risk. Some authors however challenged disciplines to reconsider both the benefits of human contact (e.g. Nicholls and Holmes, 2012; Airosa et al., 2016) and conceptions of body and personhood (e.g. Twigg et al., 2011; Nicholls and Holmes, 2012) in order for health professions to engage with broader aspects of contemporary health and wellness.

\section{Third Order findings}

The purpose of this final level of synthesis is to provide overarching meaning and insights which transcend the original data sources, whilst capturing the iterative development through first and second levels of analysis. In Table 5, five themes that represent the synthesis of findings are outlined. For each theme, we give some examples of the issues that are embedded in the theme. We then map these themes back to the threshold concept characteristics.

INSERT TABLE 5 ABOUT HERE

\section{Discussion}


Running title: Synthesis of professional touch explored using the threshold concept framework

We have described the process and emergent findings from a QRS of professional touch in the context of a wide range of health professional education and practice. The TCF provided a conceptual lens and allowed a depth of analysis and synthesis previously absent from the literature. An initial hypothesis was that the characteristics of threshold concepts would provide a useful framework for exploring professional touch, and all levels of the QRS support this proposition.

We have identified several ways in which professional touch is distinct from other concepts. Threshold concepts are usually 'bounded', having clear boundaries between other conceptual areas, which Meyer and Land (2005) suggest may define academic or disciplinary areas. Notwithstanding Cousin's (2007) observation that threshold concept theory "appreciates the contingent, contextual, historical and contested nature of any concept any discipline” (p.2), this synthesis shows that professional touch in the health professions appears to have fluid boundaries, whilst also having its own unique complexities that differ to any other form of touch. Furthermore, while irreversibility as a threshold characteristic did not emerge prominently in the literature, our findings highlight the distinctiveness of professional touch as, on one hand defining practice, yet on the other, so natural, instinctive and fundamental that it is difficult (but not impossible) to unlearn. This seems to be a very crucial characteristic. As the third level themes show, professional touch is rich and complex, and there may be circumstances where practitioners have not fully crossed the threshold of understanding touch with all its nuance. Contexts or situations that 'trouble' understanding demand learners revisit the threshold concept. Rather than unlearning the broad concept of professional touch, we refine and change aspects of our understanding.

We found many rich examples of the characteristics of TCF in our review. In particular, the transformative, troublesome and integrative aspects of professional touch came through strongly. Whilst in some respects this is no great surprise, an explicit acknowledgement of the 
Running title: Synthesis of professional touch explored using the threshold concept framework

impact of coming to understand and engage with touch is valuable for practitioners. Our data underlines the value and primacy of touch in practice and points to the importance of recognising and mitigating the processes and systems culture change that seeks to undermine or remove touch.

The third order themes have both face validity and are reflected in the literature beyond the papers reviewed. The idea that "touch is more than touch" (Verghese, 2009, p.1178) is borne out in the synthesis. Our findings show that the act of touching creates a connection, or a barrier, affecting both parties and is a form of communication on many levels. The idea that practitioners can be changed by touch, and the evidence supporting its relational qualities that link to presence, mindfulness, resilience and compassion, suggests that professional touch can provide an important means of combatting workplace stress. Our synthesis also uncovered the darker sides of touch; risk, power differentials and the possibility of harm. The discourse of touch also says something about the gaze of the individual or the profession; the influence of policy, codes of conduct and systems, sometimes reducing power distance and at other times extending it. Since completing our synthesis, Kelly et al. (2018) have published a metaethnographic line-of-argument synthesis concerned with the practice of touch in healthcare. Our approach was broader, seeking to frame professional touch in a theoretical model that helps to both understand and learn it. Their findings emphasise relational and contextual issues (e.g. boundaries, power, gender, risk and control) which are also findings in our study. Our work explores and develops these issues using a different lens and highlights, in particular, the multiple meanings and nuances of touch and the many ways it can be transformative. A strength of our synthesis is that it is theory-driven, providing a theoretical framework that facilitates discussion and action - crucially the learning journey.

Limitations and reflexivity - We chose to exclude the patient perspective from our review, focusing on how practitioners and students learnt and embedded professional touch. Where 
Running title: Synthesis of professional touch explored using the threshold concept framework

the professional perspective raised issues about the role and voice of patients, these are included in our themes. But we recognise that this is not a substitute for examining the literature from the patient viewpoint. A future review of patient perspectives on touch is likely to offer additional valuable insights. The nature of a QRS review required us to narrow down our initial search period in order to provide a practical and appropriate sample. Many of the papers refer back to earlier work and the QRS approach draws on the whole paper in each instance. Therefore we feel confident that contemporary issues in professional touch, from a practitioner perspective, are unlikely to have been missed. We recognise the contexts that each us bring to the review. All four authors are health professionals, are or have been involved in practice, and are involved in delivering health professional education. We have all explored TCF and found it a valuable framework for think about our broad practice. In addition, we were drawn together by our experiences and observations of learning and teaching professional touch. All of which represent a piori positions, but important starting points for conducting this review.

In undertaking this study we were interested in how professional touch is nuanced, by how it is viewed at an individual or professional cultural level (gaze) and communicated (both with and without words). This may be why the idea of touch as a tool, which is implicit within the literature, was not specifically highlighted in our synthesis. Certainly the QRS confirms that talking about non-verbal communication as a simple aspect of, or adjunct to, verbal communication is overly simplistic; professional touch has a whole language of its own. The time has come to teach and learn professional touch in all of its complexity.

The practical consequence of basing our synthesis on the TCF is that it offers an in-built structure that allows academics, students and practitioners to consider whether they practice professional touch, where and why they may be troubled by it, some common areas of liminality, and a framework for transformation and competence. A significant majority of 
Running title: Synthesis of professional touch explored using the threshold concept framework

articles analysed in the QRS highlight that health professional curricula rarely include learning about professional touch. An understanding of transformative and troublesome concepts has proved useful in informing the focus and design of curricula in a range of settings, including in healthcare (Barradell and Peseta, 2017). The findings of this study, framed using TCF, provided a springboard for opening up learning conversations and designing learning activities. The TCF can also provide insights into those moments where we switch from unconscious competence into conscious incompetence (Broadwell, 1969). There may be new contexts or insights with experience that cause us to reassess and regain competence in professional touch - a cyclical process, rather than a linear threshold crossing, which is at the heart of professional practice. Our synthesis provides a framework for identifying the potential source of our uncertainty in those new contexts and can help to bring about transformation once again.

\section{Conclusion}

Our analysis provides evidence that professional touch is a threshold concept. Touch has many roles and many manifestations (Watson, 1972). However, the concept of professional touch, simply as a technique employed as part of patient assessment, therapy and procedural care, is not the threshold here. Rather, it is what we learn in the process of using and reflecting on touch that transforms us. Learning to percuss, bathe a patient, or insert a cannula are skills; doing it professionally, with humanity, and understanding of the inherent challenges of touch signifies transition from layperson to professional practitioner. We acknowledge that our synthesis was from the health professional perspective and would see a review of touch from the patient perspective as a valuable complement to this work. To recognise touch as a form of dialogue, with complex meanings, complex boundaries and the potential to bring about change - that is the threshold concept. This QRS has provided new 
Running title: Synthesis of professional touch explored using the threshold concept framework

insights into how touch can be viewed, learned and practised. 
Running title: Synthesis of professional touch explored using the threshold concept framework

\section{Acknowledgements}

We would like to thank Sarah Craig for her work as a research assistant for this literature synthesis.

\section{Funding}

This literature synthesis was supporting by a small grant from the Faculty of Medical \& Health Sciences at the University of Auckland. This grant covered the cost of the research assistant time in conducting the initial literature search. 
Running title: Synthesis of professional touch explored using the threshold concept framework

\section{References}

Airosa, F., Falkenberg, T., Öhlén, G., \& Arman, M. (2016). Tactile Massage as Part of the Caring Act: A Qualitative Study in Short-Term Emergency Wards. Journal of Holistic Nursing, 34(1), 13-23.

Barradell, S., \& Peseta, T. (2017). Putting threshold concepts to work in health sciences: insights from a qualitative research synthesis. Teaching in Higher Education, 22(3), 349-372.

Bjorbækmo, W.S., \& Mengshoel, A.M. (2016). "A touch of physiotherapy" - the significance and meaning of touch in the practice of physiotherapy. Physiotherapy Theory \& Practice, 32(1), 10-19.

Broadwell, M.M. (1969). Teaching for learning (XVI.). The Gospel Guardian, 20(41), 1-3.

Burns, S. (2015). Using touch as a way to manage aggression. Mental Health Practice, 19(3), 27-33.

Carel, H., \& Macnaughton, J. (2012). “How do you feel?”: oscillating perspectives in the clinic. The Lancet, 379(9834), 2334-2335.

Cocksedge, S., George, B., Renwick, S., \& Chew-Graham, C.A. (2013). Touch in primary care consultations: qualitative investigation of doctors' and patients' perceptions. British Journal of General Practice, 63(609), e283-290.

Cohen, R.L. (2011). Time, space and touch at work: body work and labour process (re)organisation. Sociology of Health and Wellness, 33(2), 189-205.

Chang, S. O. (2001). The conceptual structure of physical touch in caring. Journal of Advanced Nursing, 33(6), 820-827. 
Running title: Synthesis of professional touch explored using the threshold concept framework

Cousin, G. (2007, April). Exploring threshold concepts for linking teaching and research. (Paper presented at International Colloquium: International Policies and Practices for Academic Enquiry, Winchester, UK).

Cousin, G. (2006). An introduction to threshold concepts. Planet, 17(1), 4-5.

Draper, J. (2014). Embodied practice: rediscovering the 'heart' of nursing. Journal of Advanced Nursing, 70(10), 2235-2244.

Edwards, C.S. (1998). An anthropological interpretation of nurses' and patients' perceptions of the use of space and touch. Journal of advanced nursing, 28(4), 809-817.

Elkiss, M.L., \& Jerome, J.A. (2012). Touch - more than a basic science. Journal of the American Osteopathic Association, 112(8), 514-517.

Flanagan, M. (2018). Threshold concepts: Undergraduate teaching, postgraduate training and professional development: A short introduction and bibliography. Accessed October 8, 2018, from https://www.ee.ucl.ac.uk/ mflanaga/thresholds.html

Gadow, S. (1984). Touch and technology: Two paradigms of patient care. Journal of Religion and Health, 23(1), pp.63-69.

Gallace, A., \& Spence, C. (2010). The science of interpersonal touch: an overview. Neuroscience \& Biobehavioral Reviews, 34(2), 246-259.

Gleeson, M., \& Timmins, F. (2004). The use of touch to enhance nursing care of older person in long term mental healthcare facilities. Journal of Psychiatric and Mental Health Nursing, 11(5), 541-545.

Goetz, J.L. (2010). Compassion: An Evolutionary Analysis and Empirical Review. Psychological Bulletin, 136(3), 351-374. 
Running title: Synthesis of professional touch explored using the threshold concept framework

Green, C. (2013). Philosophic reflections on the meaning of touch in nurse-patient interactions. Nursing Philosophy, 14(4), 242-253.

Haslam, D. (2012). The healing touch. Practitioner, 256(1749), 31.

Jones, T., \& Glover, L. (2014). Exploring the psychological processes underlying touch: lessons from the Alexander Technique. Clinical Psychology \& Psychotherapy, 21(2), $140-153$.

Kelly, M., Tink, W., Nixon, L., \& Dornan, T. (2015). Losing touch? Refining the role of physical examination in family medicine. Canadian Family Physician, 61(12), 10411043.

Kelly, M.A., Nixon, L., McClurg, C., Scherpbier, A., King, N., \& Dornan, T. (2018).

Experience of touch in healthcare: a meta-ethnography across the healthcare professions. Qualitative health research, 28(2), 200-212.

Kosak, J. (2016). Interpretations of the Healer's Touch in the Hippocratic Corpus. Studies in Ancient Medicine, 45, 247-264.

Land, R. (2011, October). Threshold Concepts and Troublesome Knowledge. (Paper presented at: Threshold Concepts Symposium. Cork, Ireland).

Land, R., Cousin, G., Meyer, J.H.F, \& Davies, P. (2005). Threshold concepts and troublesome knowledge (3): implications for course design and evaluation. (In C. Rust (Ed.), Improving Student Learning - diversity and inclusivity, Proceedings of the 12th Improving Student Learning Conference (pp. 53-64). Oxford: Oxford Centre for Staff and Learning Development [OCSLD].)

Land, R. (2016). Toil and trouble: Threshold concepts in a pedagogy of uncertainty. (In R. 
Running title: Synthesis of professional touch explored using the threshold concept framework

Land, J.H.F. Meyer, \& M.T. Flanagan (Eds.), Threshold concepts in practice (pp. 1124). Rotterdam: Sense Publishers.)

Major, C., \& Savin-Baden. M. (2010). An introduction to Qualitative Research Synthesis: Managing the Information Explosion in Social Science Research. London, Routledge.

Merleau-Ponty, M. (1962) Phenomenology of Perception. C. Smith (translator). Routledge \& Kegan Paul.

Meyer, J.H.F., \& Land, R. (2003). Threshold concepts and troublesome knowledge: linkages to ways of thinking and practising. (In C. Rust (Ed.), Improving Student Learning diversity and inclusivity, Proceedings of the 12th Improving Student Learning Conference (pp. 412-424). Oxford: Oxford Centre for Staff and Learning Development [OCSLD].)

Meyer, J. H. F., \& Land, R. (2005). Threshold Concepts and Troublesome Knowledge (2):

Epistemological Considerations and a Conceptual Framework for Teaching and Learning. Higher Education 49(3), 373-388.

Moffatt, F., \& Kerry, R. (2018). The desire for "hands-on" therapy - a critical analysis of the phenomenon of touch. (In B. E. Gibson, D. A. Nicholls, J. Setchell, \& K. Synne Groven (Eds.), Manipulating practices: A critical physiotherapy reader (pp.174-193). Cappelen Damm Akademisk/NOASP (Nordic Open Access Scholarly Publishing).

Neve, H., Wearn, A., \& Collett, T. (2016). What are threshold concepts and how can they inform medical education? Medical Teacher 38(8), 850-853.

Nicholls, D.A., \& Holmes, D. (2012). Discipline, desire, and transgression in physiotherapy practice. Physiotherapy Theory \& Practice, 28(6) 454-465. 
Running title: Synthesis of professional touch explored using the threshold concept framework

Nicholls, D., Johnson, A., \& Edenborough, M. (2013). Touch, the essence of caring for people with end-stage dementia: A mental health perspective in Namaste Care. Aging \& Mental Health, 17(5), 571-578.

Paterson, B.L., Thorne, S.E., Canam, C., \& Jillings, C. (2001). Meta-study of qualitative health research: A practical guide to meta-analysis and meta-synthesis (Vol. 3). Sage.

Peloquin, S.M. (1989). Helping through touch: the embodiment of caring. Journal of Religion and Health, 28(4), 299-322.

Perkins, D. (2006). Constructivism and troublesome knowledge. (In J.H.F. Meyer, \& R. Land (Eds.), Overcoming barriers to student understanding: Threshold concepts and troublesome knowledge (pp. 33-47). London: Routledge.)

Picco, E., Santoro, R., \& Garrino, L. (2010). Dealing with the patient's body in nursing: nurses' ambiguous experience in clinical practice. Nursing Inquiry, 17(1), 39-46.

Polizzi, M.G. (2015). Simple acts. Nursing, 45(5), 52-53.

Ranheim, A., Kärner, A., Arman, M., Rehnsfeldt, A.W., \& Berterö, C. (2010). Embodied reflection in practice - 'touching the core of caring'. International Journal of Nursing Practice, 16(3), 241-247.

Sibbett, C., \& Thompson, W. (2008). Nettlesome knowledge, liminality and the taboo in cancer and art therapy experiences. (In R. Land, J.H.F. Meyer, \& J. Smith (Eds.), Threshold concepts within the disciplines. (pp. 227-42). Rotterdam: Sense Publishers.)

Singh, C., \& Leder, D. (2012). Touch in the consultation. British Journal of General Practice, 62(596), 147-148.

Tabatabaee, A., Tafreshi, M.Z., Rassouli, M., Aledavood, S.A., AlaviMajd, H., \& 
Running title: Synthesis of professional touch explored using the threshold concept framework

Farahmand, S.K. (2016). Effect of therapeutic touch in patients with cancer: a literature review. Medical Archives, 70(2), $142-147$.

Timmermans, J. A., \& Meyer, J. H. F. (2017). A framework for working with university teachers to create and emded 'Integrated Threshold Concept Knowledge' (ITCK) in their practice. International Journal for Academic Development. DOI 10.1080/1360144X.2017.1388241

Twigg, J., Wolkowitz, C., Cohen, R.L., \& Nettleton, S. (2011). Conceptualising body work in health and social care. Sociology of Health \& Illness, 33(2), 171-188.

Verghese, A. (2009). A touch of sense. Health Affairs, 28(4), 1177-1182.

Watson, W.H. (1975) The meanings of touch: Geriatric nursing. Journal of Communication. 25(3), 104-12.

Whiteside, J., \& Butcher, D. (2015). 'Not a job for a man': factors in the use of touch by male nursing staff. British Journal of Nursing, 24(6), 335-341. 
Running title: Synthesis of professional touch explored using the threshold concept framework

Table 1: Characteristics of Threshold Concepts

\begin{tabular}{|c|c|}
\hline Characteristic * & Descriptor \\
\hline Transformative & $\begin{array}{l}\text { Once understood the concept changes the way someone thinks } \\
\text { about, interprets or views their discipline. }\end{array}$ \\
\hline Troublesome & $\begin{array}{l}\text { Knowledge that is inherently challenging. It may be } \\
\text { counterintuitive, alien, confronting or appear incoherent. }\end{array}$ \\
\hline Irreversible & Once learnt, it is impossible or difficult to unlearn. \\
\hline Integrative & $\begin{array}{l}\text { Brings together different aspects of a subject that were } \\
\text { previously regraded as unrelated. }\end{array}$ \\
\hline Bounded & $\begin{array}{l}\text { Delineates a particular conceptual space serving a specific and } \\
\text { limited purpose }\end{array}$ \\
\hline Discursive & Results in enhanced and extended use of language \\
\hline Reconstitutive & There is a shift in learner subjectivity over time \\
\hline Liminal & $\begin{array}{l}\text { The feeling of being in a cognitive space between an old } \\
\text { understanding and the new. There can be oscillation between the } \\
\text { two states. }\end{array}$ \\
\hline
\end{tabular}

* Meyer and Land, 2003; Land, 2011 
Running title: Synthesis of professional touch explored using the threshold concept framework

Table 2: Inclusion and exclusion criteria used to refine search and selection

Search terms: Physiotherap* OR nurs* OR allied health OR doctor; Physical examination; Patient; Professional practice; Socialization; Therapeutic touch; Delivery of healthcare; Nursing care; Touch.

\begin{tabular}{|l|l|}
\hline Include & Exclude \\
\hline $\begin{array}{l}\text { Initially - Sources between } 1990-2016 \\
\text { Finally - Sources between } 2010-2016\end{array}$ & Pre-1990 sources \\
\hline $\begin{array}{l}\text { Sources describing the use and role of } \\
\text { touch in clinical professional practice and/or } \\
\text { clinical learning }\end{array}$ & $\begin{array}{l}\text { Sources that describe touch solely in terms } \\
\text { of the mechanics of physical examination, } \\
\text { procedures or treatment (no nuance) }\end{array}$ \\
\hline $\begin{array}{l}\text { Sources that include discussion of touch in } \\
\text { the socialisation of health professionals and } \\
\text { students }\end{array}$ & Sources focusing on the patient perspective \\
\hline $\begin{array}{l}\text { International literature } \\
\text { Peer reviewed journal articles, book } \\
\text { chapters, } \\
\text { personal views and letters in peer reviewed } \\
\text { journals, grey literature that meets other } \\
\text { criteria }\end{array}$ & Reports, conference proceedings, theses \\
\hline $\begin{array}{l}\text { Qualitative studies e.g. case study, narrative } \\
\text { inquiry, ethnography, phenomenology, } \\
\text { participatory action research, grounded } \\
\text { theory, syntheses/reviews and mixed } \\
\text { method studies }\end{array}$ & $\begin{array}{l}\text { Quantitative studies and quantitative } \\
\text { literature reviews }\end{array}$ \\
\hline
\end{tabular}


Table 3: Articles included in synthesis

\begin{tabular}{|c|c|c|c|c|c|}
\hline Article & Aims / purpose & Discipline/setting & Country & $\begin{array}{l}\text { Aspect of professional } \\
\text { touch }\end{array}$ & Research approach \\
\hline Airosa et al. (2016) & $\begin{array}{l}\text { To explore nurses' } \\
\text { lived experience } \\
\text { associated and meaning } \\
\text { in giving 'tactile } \\
\text { massage' whilst caring } \\
\text { for patients in short } \\
\text { term emergency wards }\end{array}$ & $\begin{array}{l}\text { Nursing (registered and } \\
\text { assistant) / Two } \\
\text { Emergency } \\
\text { Departments }\end{array}$ & Sweden & $\begin{array}{l}\text { Tactile massage } \\
\text { (training provided as } \\
\text { part of study) }\end{array}$ & $\begin{array}{l}\text { Phenomenological- } \\
\text { hermeneutic using } \\
\text { individual interviews } \\
(n=14)\end{array}$ \\
\hline $\begin{array}{l}\text { Bjorbækmo \& } \\
\text { Mengshoel (2016) }\end{array}$ & $\begin{array}{l}\text { To explore and } \\
\text { elaborate on the } \\
\text { meaning and } \\
\text { significance of touch in } \\
\text { the practice of } \\
\text { physiotherapy }\end{array}$ & $\begin{array}{l}\text { Physiotherapy / } \\
\text { Physiotherapy practice }\end{array}$ & Norway & $\begin{array}{l}\text { Touch in physiotherapy } \\
\text { practice }\end{array}$ & $\begin{array}{l}\text { Phenomenological. } \\
\text { Observations }(n=16) \\
\text { and interviews with } \\
\text { physiotherapists }(n=9) \text {; } \\
\text { interviews with patients } \\
(n=9)\end{array}$ \\
\hline Burns (2015) & $\begin{array}{l}\text { To examine the } \\
\text { practice and } \\
\text { implications } \\
\text { of using touch as a } \\
\text { form of non-verbal } \\
\text { communication } \\
\text { with patients who are } \\
\text { in distress }\end{array}$ & $\begin{array}{l}\text { Nursing team / Where } \\
\text { patients } \\
\text { are experiencing } \\
\text { distress, confusion and } \\
\text { fear }\end{array}$ & United Kingdom & $\begin{array}{l}\text { Expressive touch } \\
\text { framed as key aspect of } \\
\text { non-verbal } \\
\text { communication }\end{array}$ & Conceptual analysis \\
\hline $\begin{array}{l}\text { Carel \& Macnaughton } \\
\text { (2012) }\end{array}$ & $\begin{array}{l}\text { Exploration of touch in } \\
\text { clinical practice using } \\
\text { the phenomenolgical } \\
\text { view of duality - the } \\
\text { physical experience } \\
\text { and the consciousness } \\
\text { experience }\end{array}$ & Healthcare / All health & $\mathrm{N} / \mathrm{A}$ & $\begin{array}{l}\text { subjectivity and } \\
\text { objectivity of touch }\end{array}$ & $\begin{array}{l}\text { Viewpoint, } \\
\text { phenomenological lens }\end{array}$ \\
\hline Cocksedge et al. (2013) & $\begin{array}{l}\text { To explore experiences } \\
\text { of patient's and general } \\
\text { practitioner's }\end{array}$ & $\begin{array}{l}\text { General Practice / } \\
\text { urban and semi-rural } \\
\text { practice }\end{array}$ & United Kingdom & $\begin{array}{l}\text { Any form of touch in } \\
\text { the consultation }\end{array}$ & $\begin{array}{l}\text { Individual semi- } \\
\text { structured interviews } \\
\text { with GP's }(n=15) \text { and }\end{array}$ \\
\hline
\end{tabular}


Running title: Synthesis of professional touch explored using the threshold concept framework

\begin{tabular}{|c|c|c|c|c|c|}
\hline & $\begin{array}{l}\text { experience of using } \\
\text { touch in consultations }\end{array}$ & & & & $\begin{array}{l}\text { their patients }(\mathrm{n}=11) \text {. } \\
\text { Constant comparative } \\
\text { analysis }\end{array}$ \\
\hline Cohen (2011) & $\begin{array}{l}\text { To examine the } \\
\text { challenges involved in } \\
\text { work which views } \\
\text { bodies as objects of the } \\
\text { work or material of } \\
\text { production }\end{array}$ & $\begin{array}{l}\text { Health and Social Care } \\
\text { / All health }\end{array}$ & N/A & $\begin{array}{l}\text { 'body work': the touch, } \\
\text { manipulation or } \\
\text { physical } \\
\text { constraint of bodies }\end{array}$ & Conceptual analysis \\
\hline Draper (2014) & $\begin{array}{l}\text { To explore the } \\
\text { importance of } \\
\text { embodiment in nursing } \\
\text { and to examine } \\
\text { different sources of } \\
\text { authoritative } \\
\text { knowledge concerning } \\
\text { the body and } \\
\text { embodiment }\end{array}$ & Nursing / All health & N/A & $\begin{array}{l}\text { Nursing as a body- } \\
\text { based practice }\end{array}$ & Conceptual analysis \\
\hline Elkiss \& Jerome (2010) & $\begin{array}{l}\text { To provide a rationale } \\
\text { for osteopaths to } \\
\text { routinely use touch in } \\
\text { their practice }\end{array}$ & $\begin{array}{l}\text { Osteopathy / } \\
\text { Osteopathic practice }\end{array}$ & N/A & Touch by osteopaths & Conceptual analysis \\
\hline Goetz (2010) & $\begin{array}{l}\text { To analyse } \\
\text { 'compassion' }\end{array}$ & N/A & N/A & N/A & $\begin{array}{l}\text { Literature review - } \\
\text { Evolutionary Analysis } \\
\text { and Empirical Review }\end{array}$ \\
\hline Green (2013) & $\begin{array}{l}\text { To explore the meaning } \\
\text { of touch in the nurse- } \\
\text { patient relationship, } \\
\text { using a contemporary } \\
\text { theory of touch }\end{array}$ & Nursing / All health & N/A & $\begin{array}{l}\text { Tactile interaction } \\
\text { between nurses and } \\
\text { their patients }\end{array}$ & Conceptual analysis \\
\hline Haslam (2012) & $\begin{array}{l}\text { Provides an argument } \\
\text { as to why touch matters } \\
\text { in a healthcare } \\
\text { landscape where new }\end{array}$ & $\begin{array}{l}\text { Medicine (although } \\
\text { makes reference to } \\
\text { other health } \\
\text { professions) / All health }\end{array}$ & N/A & $\begin{array}{l}\text { Broad purposes of } \\
\text { touch in the clicnial } \\
\text { setting, e.g. contact, } \\
\text { intimacy, therapy }\end{array}$ & Personal view \\
\hline
\end{tabular}


Running title: Synthesis of professional touch explored using the threshold concept framework

\begin{tabular}{|c|c|c|c|c|c|}
\hline & $\begin{array}{l}\text { technologies are being } \\
\text { adopted }\end{array}$ & & & & \\
\hline Jones \& Glover (2014) & $\begin{array}{l}\text { To explore the } \\
\text { experience of touch in } \\
\text { the Alexander } \\
\text { Technique }\end{array}$ & $\begin{array}{l}\text { Alexander Technique / } \\
\text { training and practice }\end{array}$ & United Kingdom & $\begin{array}{l}\text { Views of Alexander } \\
\text { Technique pupils about } \\
\text { the experience of } \\
\text { learning through and } \\
\text { about touch }\end{array}$ & $\begin{array}{l}\text { Mixed-methods. } \\
\text { Interviews }(n=6) \text { and } \\
\text { surveys }(n=111)\end{array}$ \\
\hline Kosak (2016) & $\begin{array}{l}\text { Historical analysis of } \\
\text { gender and touch as } \\
\text { represented in } \\
\text { Hippocratic Corpus }\end{array}$ & Medicine & $\mathrm{N} / \mathrm{A}$ & $\begin{array}{l}\text { Acknowledgment of } \\
\text { different types as } \\
\text { represented in ancient } \\
\text { texts }\end{array}$ & Conceptual analysis \\
\hline $\begin{array}{l}\text { Nicholls \& Holmes } \\
\text { (2012) }\end{array}$ & $\begin{array}{l}\text { To examine the } \\
\text { relationship between } \\
\text { sensuality and } \\
\text { physiotherapy practice } \\
\text { and explore the } \\
\text { contribution of } \\
\text { sensuality to } \\
\text { physiotherapy's } \\
\text { professional } \\
\text { identity }\end{array}$ & $\begin{array}{l}\text { Physiotherapy / } \\
\text { Physiotherapy practice }\end{array}$ & N/A & $\begin{array}{l}\text { Body work (work that } \\
\text { focuses directly on the } \\
\text { bodies of others in } \\
\text { some way including } \\
\text { assessment diagnosis, } \\
\text { handling and treatment) }\end{array}$ & $\begin{array}{l}\text { Conceptual analysis. } \\
\text { Drawing on the work } \\
\text { of three postmodern } \\
\text { philosophers }\end{array}$ \\
\hline Nicholls et al. (2013) & $\begin{array}{l}\text { To explore the } \\
\text { implementation of a } \\
\text { 'high touch' model of } \\
\text { care for people with } \\
\text { advanced dementia }\end{array}$ & $\begin{array}{l}\text { Nursing (registered and } \\
\text { assistant) and family } \\
\text { members / Aged care } \\
\text { facility }\end{array}$ & Australia & $\begin{array}{l}\text { Non-therapeutic touch } \\
\text { that is part of day to } \\
\text { day life }\end{array}$ & $\begin{array}{l}\text { Focus groups ( } 7 \text { groups } \\
\text { with } 31 \text { participants) as } \\
\text { one aspect of a larger } \\
\text { mixed methods project }\end{array}$ \\
\hline Picco et al. (2010) & $\begin{array}{l}\text { To explore the } \\
\text { experiences of nurses } \\
\text { in their day-to-day } \\
\text { interaction with } \\
\text { patients, with a } \\
\text { particular focus on } \\
\text { body care }\end{array}$ & $\begin{array}{l}\text { Nursing / General } \\
\text { medicine, neurology } \\
\text { and geriatrics }\end{array}$ & Italy & $\begin{array}{l}\text { Touch as part of caring } \\
\text { for patients and their } \\
\text { bodies }\end{array}$ & $\begin{array}{l}\text { Phenomenological. } \\
\text { Interviews }(n=14)\end{array}$ \\
\hline Polizzi (2015) & $\begin{array}{l}\text { Reflection on a } 30 \text {-year } \\
\text { career as nurse }\end{array}$ & Nursing / All health & N/A & Touch as a simple act & $\begin{array}{l}\text { Personal view with } \\
\text { example case histories }\end{array}$ \\
\hline
\end{tabular}


Running title: Synthesis of professional touch explored using the threshold concept framework

\begin{tabular}{|l|l|l|l|l|l|}
\hline Ranheim et al. (2010) & $\begin{array}{l}\text { To clarify the } \\
\text { integration of the } \\
\text { caring act of touch with } \\
\text { reflection on caring } \\
\text { theory }\end{array}$ & Nursing / Elderly care & Sweden & $\begin{array}{l}\text { Rhythmical } \\
\text { Embrocation (a type of } \\
\text { massage performed } \\
\text { with a caring intention) }\end{array}$ & $\begin{array}{l}\text { phenomenological- } \\
\text { hermeneutic approach } \\
\text { inspired by the } \\
\text { philosophy of Ricoeur. } \\
\text { Interviews (n=7) }\end{array}$ \\
\hline Twigg et al. (2011) & $\begin{array}{l}\text { To identify some of the } \\
\text { characteristics of body } \\
\text { Work in helath and } \\
\text { social care, its links } \\
\text { with existing areas of } \\
\text { research interest, and } \\
\text { any new insights }\end{array}$ & $\begin{array}{l}\text { health and social care } \\
\text { workers / All health }\end{array}$ & United Kingdom & $\begin{array}{l}\text { Body work (work that } \\
\text { focuses directly on the } \\
\text { bodies of others in } \\
\text { some way including } \\
\text { assessment diagnosis, } \\
\text { handling and treatment) }\end{array}$ & $\begin{array}{l}\text { Conceptual analysis } \\
\text { Whiteside and Butcher } \\
\text { (2015) }\end{array}$ \\
$\begin{array}{l}\text { To explore and } \\
\text { critically } \\
\text { review the factors that } \\
\text { influence the } \\
\text { perception and use of } \\
\text { touch } \\
\text { by male nursing staff in } \\
\text { contemporary } \\
\text { healthcare settings }\end{array}$ & $\begin{array}{l}\text { Nursing (male staff) / health } \\
\text { All }\end{array}$ & N/A & $\begin{array}{l}\text { Any form of touch } \\
\text { employed by male } \\
\text { nurses in clinical } \\
\text { situations }\end{array}$ & $\begin{array}{l}\text { Systematic literature } \\
\text { review (11 studies) - } \\
\text { qualitative approach }\end{array}$ \\
\hline
\end{tabular}

N/A = Not Applicable 
Running title: Synthesis of professional touch explored using the threshold concept framework

Table 4: Threshold characteristics identified in first order synthesis

\begin{tabular}{|c|c|c|c|c|c|c|c|c|}
\hline Article & 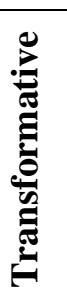 & 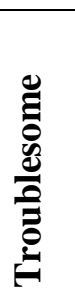 & 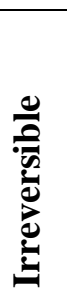 & 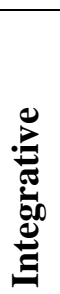 & 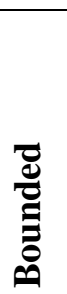 & 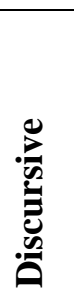 & 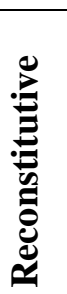 & 焉 \\
\hline Airosa et al. (2016) & $\mathrm{X}$ & $\mathrm{X}$ & & $\mathrm{X}$ & & & $\mathrm{X}$ & $\mathrm{X}$ \\
\hline $\begin{array}{l}\text { Bjorbækmo and Mengshoel } \\
\text { (2016) }\end{array}$ & $\mathrm{X}$ & & & $\mathrm{X}$ & & $\mathrm{X}$ & & \\
\hline Burns (2015) & $\mathrm{X}$ & $\mathrm{X}$ & & $\mathrm{X}$ & $\mathrm{X}$ & $\mathrm{X}$ & $\mathrm{X}$ & \\
\hline Carel and Macnaughton (2012) & $\bar{X}$ & $\mathrm{X}$ & & & & $\mathrm{X}$ & $\mathrm{X}$ & \\
\hline Cocksedge et al. (2013) & $\mathrm{X}$ & $\mathrm{X}$ & $\mathrm{X}$ & $\mathrm{X}$ & $\mathrm{X}$ & $\mathrm{X}$ & $\mathrm{X}$ & $\mathrm{X}$ \\
\hline Cohen (2011) & & $\mathrm{X}$ & & & & & & \\
\hline Draper (2014) & & $\mathrm{X}$ & & & $\mathrm{X}$ & & & \\
\hline Elkiss and Jerome (2010) & & & & $\mathrm{X}$ & & & & \\
\hline Goetz (2010) & & $\mathrm{X}$ & & $\mathrm{X}$ & $\mathrm{X}$ & & & $\mathrm{X}$ \\
\hline Green (2013) & $\mathrm{X}$ & $\mathrm{X}$ & & & $\mathrm{X}$ & & & $\mathrm{X}$ \\
\hline Haslam (2012) & $\mathrm{X}$ & $\mathrm{X}$ & & $\mathrm{X}$ & $\mathrm{X}$ & $\mathrm{X}$ & & \\
\hline Jones and Glover (2014) & $X$ & $X$ & $X$ & $\mathrm{X}$ & $\mathrm{X}$ & $\mathrm{X}$ & $\mathrm{X}$ & $X$ \\
\hline Kosak (2016) & $\mathrm{X}$ & $\mathrm{X}$ & & & $X$ & & & \\
\hline Nicholls and Holmes (2012) & $\mathrm{X}$ & $\mathrm{X}$ & & $\mathrm{X}$ & $\mathrm{X}$ & $\mathrm{X}$ & $\mathrm{X}$ & $\mathrm{X}$ \\
\hline Nicholls et al. (2013) & $\mathrm{X}$ & & & $\mathrm{X}$ & & & & \\
\hline Picco et al. (2010) & & $\mathrm{X}$ & & & & & & \\
\hline Polizzi (2015) & $\mathrm{X}$ & $\mathrm{X}$ & & & & & & \\
\hline Ranheim et al. (2010) & $\mathrm{X}$ & & & $X$ & & & & \\
\hline Twigg et al. (2011) & $\mathrm{X}$ & $\mathrm{X}$ & $X$ & $\mathrm{X}$ & $\mathrm{X}$ & $\mathrm{X}$ & $\mathrm{X}$ & $\mathrm{X}$ \\
\hline Whiteside and Butcher (2015) & & $\mathrm{X}$ & & & $\mathrm{X}$ & $\mathrm{X}$ & & $\mathrm{X}$ \\
\hline
\end{tabular}


Running title: Synthesis of professional touch explored using the threshold concept framework

Table 5: Third Order Themes, with mapping to threshold characteristics

$\mathrm{X}=$ Maps to characteristic, $(\mathrm{X})=$ Weaker map to characteristic

\begin{tabular}{|c|c|c|c|c|c|c|c|c|}
\hline Third Order Theme & & 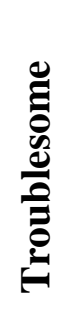 & 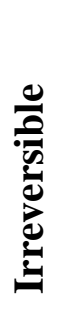 & 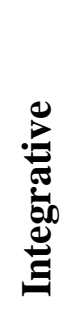 & 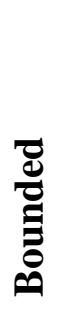 & 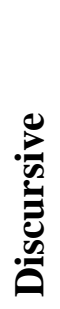 & 葛 & 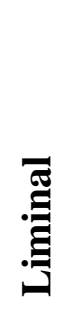 \\
\hline $\begin{array}{l}\text { Touch as Dialogue } \\
\text { Language, listening/reading, 'speaking'/conveying } \\
\text { meaning without words, reciprocity, expression of } \\
\text { emotion, more than words/transcendence, } \\
\text { relationship building }\end{array}$ & $X$ & $(\mathrm{X})$ & & $X$ & $\mathrm{X}$ & $X$ & $X$ & $\mathrm{X}$ \\
\hline $\begin{array}{l}\text { Being changed by touch } \\
\text { Self-aware/care, other-aware, wellbeing, relaxation, } \\
\text { satisfaction, presence, confidence, distress, unease, } \\
\text { exhaustion }\end{array}$ & $\mathrm{X}$ & $X$ & $\mathrm{X}$ & & & & $\mathrm{X}$ & $\mathrm{X}$ \\
\hline $\begin{array}{l}\text { Boundaries of touch } \\
\text { Transgression, intimacy, context, challenge, } \\
\text { self/other, discomfort/pain, fear, danger, risk, } \\
\text { stigma, fluidity of boundaries, professional culture, } \\
\text { power }\end{array}$ & $\mathrm{X}$ & $X$ & & $\mathrm{X}$ & $\mathrm{X}$ & & $\mathrm{X}$ & $\mathrm{X}$ \\
\hline $\begin{array}{l}\text { Multiple meanings of touch } \\
\text { Genuineness/trust, lens/view [machine, system, } \\
\text { mind-body], work, interaction of head/hand/heart, } \\
\text { holistic vs. simple tool } \\
\text { (diagnostic/therapeutic/expressive) }\end{array}$ & $\mathrm{X}$ & $\mathrm{X}$ & & $X$ & $\mathrm{X}$ & $\mathrm{X}$ & $\mathrm{X}$ & $\mathrm{X}$ \\
\hline $\begin{array}{l}\text { Influences on touch } \\
\text { Personal beliefs/values, professional values and } \\
\text { codes of conduct, own sense of humanity, } \\
\text { ambiguity, gender, age, past/present/future } \\
\text { experience of touch, power differentials/hierarchy }\end{array}$ & $X$ & $\mathrm{X}$ & $\mathrm{X}$ & $(\mathrm{X})$ & $\mathrm{X}$ & $\mathrm{X}$ & $\mathrm{X}$ & $X$ \\
\hline
\end{tabular}

